Acta vet. scand. $1986,27,560-565$.

From the Swedish Association for Livestock Breeding and Production, Eskilstuna, Sweden, Department of Obstetrics and Gynaecology, Swedish University of Agricultural Sciences, Uppsala, Sweden, Centre de Recherche en Reproduction Animale, Fac. Med. Vet. Université de Montréal, Sí-Hyacinthe, Québec, Canada and Department of Animal Breeding and Genetics, Swedish University of Agricultural

Sciences, Uppsala, Sweden.

\title{
ATTEMPTS TO STIMULATE MITOSIS IN CULTURED TROPHOBLAST CELLS OF CATTLE EMBRYOS
}

\author{
By \\ H. Gustafsson, W. A. King, B. Berglund and L. Picard
}

GUSTAFSSON, H., W. A. KING, B. BERGLUND and L. PICARD: Attempts to stimulate mitosis in cultured trophoblast cells of cattle embryos. Acta vet. scand. 1986, 27, 560-565. - Trophoblast from Day-14 bovine embryos was cultured in medium containing mitogens to determine if the mitotic index could be altered. Trophoblast from each of 15 embryos was cultured in minimum essential medium (Eagles) with $20 \%$ fetal calf serum (control) or in this medium supplemented with pokeweed mitogen $(1 \%, \mathrm{v} / \mathrm{v})$, phytohemagglutinin $(1 \%, \mathrm{v} / \mathrm{v})$, concanavalin $\mathrm{A}(1 \%, \mathrm{v} / \mathrm{v})$ or thymidine $(2 \mathrm{mg} / \mathrm{ml})$. No mitogenic effect was observed due to any of the treatments. However, mitotic indexes were significantly lower when pokeweed $(\mathrm{P}<0.05)$ or thymidine $(\mathrm{P}<0.01)$ was added to the medium. A highly significant $(\mathrm{P}<0.001)$ variation in mitotic index between embryos was observed.

mitogen; mitotic index; chromosome.

The embyos of farm animals such as cattle, sheep, goats, pigs and horses differ from those of laboratory species (mouse, rat and rabbit) in that they have a relatively long period before attachment to the maternal uterine epithelium occurs. This extended pre-attachment period is of particular value in that cows can be superovulated and embryos recovered from the uterus by relatively simple non-surgical techniques between Day 5 and 18 . Once recovered, the embryos can be frozen, micromanipulated, sexed, transferred to recipient females or used for research (Betteridge 1977). 
Studies involving cytogenetics and cell cycle kinetics in the embryo are restricted by low cell numbers in the early embryo or lack of mitosis and cell synchrony in the elongated blastocyst. Direct analysis or analysis after short term culture have been extensively used in cytogenetic studies of early embryos (King 1985). However, the low mitotic index in cattle and horse embryos limits the number of cells in metaphase available for examination (Romagnano et al. 1985). Increasing the number of mitosis would increase the percentage of embryos which can be sexed by cytogenetic analysis and thereby making this technique more practical for routine application to cattle embryos (Singh \& Hare 1980, Rottman 1981, King 1984).

The purpose of the present investigation was to determine if the mitotic index of Day-14 bovine trophoblast cells could be altered by exposure to mitogens known to stimulate cell division of cultured lymphocytes.

\section{MATERIAL AND METHODS}

Canadian Holstein heifers $(n=4)$ were induced to superovulate with $40 \mathrm{mg} \mathrm{FSH}^{\star}$ (8 injections of $5 \mathrm{mg}$ over 4 days) and cloprostenol $^{\star *}$ and inseminated twice, 12 and $24 \mathrm{~h}$ after estrus detection with frozen-thawed semen. Embryos were collected on Day 14 (estrus = Day 0) by a non-surgical technique using Dulbeccos phosphate buffered saline (PBS) enriched with $2 \%$ fetal calf serum (FCS). Totally 15 embryos were selected for culture and transported to the laboratory in PBS with $20 \%$ FCS where they were washed and transferred individually to culture medium consisting of Eagles minimum essential medium containing $0.20 \mathrm{mM}$ Hepes buffer, $1 \mathrm{mM}$ glutamine, $20 \%$ fetal calf serum and antibiotics (100 IU penicillin and $100 \mu \mathrm{g}$ streptomycin/ ml medium). The inner cell mass and a portion of the surrounding trophoblast were removed and the remaining trophoblast was cut into 5 to $10 \mathrm{~mm}$ pieces using 25 gauge needles. Pieces of embryos were transferred individually or in pairs to multiwell culture dishes containing $1 \mathrm{ml}$ of fresh culture medium per well. Embryos were then incubated 2 to $4 \mathrm{~h}$ at $37^{\circ} \mathrm{C}$ in a humid atmosphere to allow formation of trophoblastic spheres. At the end of this period the followig commercially prepared mitogens were

* FSH-P.: Bums-Biotec, Omaha, Nebraska.

* Estrumate: ICI Pharmaceutical, Mississauga, Ontario. 
added to the cultures: Pokeweed mitogen (GIBCO; final concentration $=1 \% \mathrm{v} / \mathrm{v}$ ), phytohemagglutinin-M (GIBCO; finla concentration $=1 \% \mathrm{v} / \mathrm{v}$ ), concanavalin A (DIFCO; final concentration $=1 \%, \mathrm{v} / \mathrm{v})$. Cultures without addition of mitogens served as controls and thymidine (Sigma; final concentration 2 $\mathrm{mg} / \mathrm{ml}$ ), which is known to block DNA replication, was added to serve as a negative control.

The trophoblastic spheres were divided among the different treatments so that spheres from the same embryo were exposed to all 5 treatments. Cultures were maintained for 24 or $48 \mathrm{~h}$ following addition of the treatment. Colcemide (GIBCO; 0.05 $\mu \mathrm{g} / \mathrm{ml}$ ) was added to each culture $2 \mathrm{~h}$ before termination. The trophoblast spheres were fixed and chromosome preparations were made as previously described (Romagnano et al. 1985). The mitotic index (number of cells in metaphase $\times 100$ /total number of cells counted) was calculated for 800 to 1000 cells per trophoblastic sphere for each treatment. The slides were coded beofre microscopic examination to prevent biased assessment of mitotic index.

The statistical analysis of the data was carried out using the GLM-procedure in the Statistical Analysis System (SAS Institute Inc. 1985). In the analysis of variance the full model included the effects of time in culture, embryo within time in culture, treatment and the interaction between time in culture and treatment. Time in culture and the interaction between this effect and treatment were found to be non-significant and therefore excluded in the final analysis. Effects of treatment were tested by estimating contrasts between the controls and mitogen exposed trophoblasts.

\section{RESULTS AND DISCUSSION}

The mean mitotic index of trophoblast spheres from the $\mathbf{1 5}$ embryos after culture in medium supplemented with mitogens are summarized in Table 1. The addition of mitogens to the culture medium did not increase the mitotic index. The mean mitotic index was lower in all of the treated groups. Comparison between treatments (Table 2) revealed a statistically significant reduction in mitotic index due to the addition of pokeweed $(\mathrm{P}<0.05)$ or thymidine $(P<0.01)$. The duration of culture did not affect the mitotic index of control samples or treated samples. There 
T a ble 1. Mitotic index for treatments (means and standard deviations).

\begin{tabular}{lcc}
\hline Treatment & Mean & SD \\
\hline Control & 0.99 & 0.64 \\
Pokeweed & 0.68 & 0.50 \\
Phytohemagglutinin-M & 0.85 & 0.60 \\
Concanavalin A & 0.84 & 0.60 \\
Thymidine & 0.57 & 0.35 \\
\hline
\end{tabular}

Table 2. Comparison between treatments (contrasts and levels of significance).

\begin{tabular}{lc}
\hline Contrast & Level of significance \\
\hline Pokeweed vs control & $0.0452^{\star}$ \\
Phytohemagglutinin-M vs control & $0.2991 \mathrm{~ns}$ \\
Concanavalin A vs control & $0.2742 \mathrm{~ns}$ \\
Thymidine vs control & $0.0058^{\star \star}$ \\
All treatments vs control & $0.0320^{\star}$ \\
\hline
\end{tabular}

was a highly significant $(\mathrm{P}<0.001)$ variation in mitotic index among embryos.

A similar lack of stimulatory effect has been observed in mouse embryos cultured in medium supplemented with pokeweed or concanavalin. Pokeweed at concentration of 1,10 or 100 $\mu \mathrm{g} / \mathrm{ml}$ blocked blastocyst formation.

Concanavalin A at the concentration of $10 \mu \mathrm{g} / \mathrm{ml}$ reduced the number of embryos which form blastocysts while at $100 \mu \mathrm{g} / \mathrm{ml}$ the formation of morulae was blocked (Menino et al. 1986). In contrast, significantly greater numbers of mouse embryos in medium supplemented with phytohemagglutinin at concentrations of $10 \mu \mathrm{g} / \mathrm{ml}$ and $100 \mu \mathrm{g} / \mathrm{ml}$ formed blastocysts and at 1 $\mu \mathrm{g} / \mathrm{ml}$ the percentage of embryos hatching from their zona pellucida was higher. Overall it was concluded that addition of $1 \mu \mathrm{g}$ phytohemagglutinin/ml medium supports superior development to the blastocyst stage and hatching (Menino et al. 1986). This is in contrast with our observations on bovine trophoblasts. However, the number of cells per mouse embryo or the mitotic index was not reported so that it is difficult to determine if a low concentration of phytohemagglutinin has a mitogenic effect on embryos. 
Thymidine, which has been shown to block mitosis in fibroblasts and lymphocytes (Xeros 1962) has a similar effect on bovine trophoblasts. It has also been used to synchronize the cell cycle of mouse blastomeres and once removed and combinated with colchicine, enhances mitosis (Rottman \& Arnold 1983). Synchronization by removal of thymidine and further culture of bovine trophoblastic spheres with colcemid was not attempted.

The highly significant differences in mitotic index between embryos emphasizes the individual variation which exists at this stage of development. This variation in mitotic index may be a reflection of variation in length and viability of embryos at this stage (Betteridge et al. 1982). Such individual variation must be taken into account in studies where comparison between embryos is made unless large numbers of embryos are used.

From the present study it may be concluded that the mitotic index of trophoblast cells can not be increased by prolonging the culture time or by the addition of phytohemagglutinin, concanavalin A, thymidine or pokeweed to the culture medium.

\section{ACKNOWLEDGEMENTS}

The technical aid of Ms. Ginette Pineault and Mireille Blacquière and the financial support of the Knut and Alice Wellenberg fund and the Natural Sciences and Engineering Research Council of Canada are gratefully acknowledged.

\section{REFERENCES}

Betteridge, K. J.: Embryo transfer in farm animals. A review of techniques and applications. Agriculture Canada Monograph No. 16, 1977.

Betteridge, K. J., E. A. Sygden, M. D. Eaglesome, G. C. B. Randall \& D. Mitchell: Plasma progesterone levels in superovulated cattle in relation to hatched embryo sizes, ovulation rates, and premature regression of corpra lutea. Anim. Reprod. Sci. 1982, 4, 207-212.

Menino, A .R., C. S. Gardiner \& J. S. Schussler: Effects of mitogenic lectins on in vitro mouse embryo development. Theriogenology 1986, 25, 173.

King, W. A.: Sexing embryos by cytological methods. Theriogenology 1984, 21, 7-17.

King, W. A.: Intrinsic embryonic factors which may affect survival after transfer. Theriogenology 1985, 23, 161-175.

Romagnano, A., W. A. King, C.-L. Richer \& M. A. Perrone: A direct technique for preparation of chromosomes from early equine embryos. Canad. J. Genet. Cytol. 1985, 27, 365-369. 
Rottman, O. J.: Chromosome preparation from single blastomeres after colcemide treatment and removed from rabbit morula - unsuitable for sexing in routine embryo transfer. Theriogenology $1981,15,32-37$.

Rottman, O. S. \& S. Arnold: Enhancing the mitotic index of blastomeres by thymidine synchronization. Anim. Reprod. Sci. 1983, $6,239-242$.

SAS Institute Inc.: SAS user's guide. SAS Institute Inc., Cary N.C. 1985.

Singh, E. L. \& W. C. D. Hare: The feasibility of sexing bovine morula stage embryos prior to embryo transfer. Theriogenology 1980, 14, $421-427$.

Xeros, N.: Deoxyriboside control and synchronization of mitosis. Nature 1962, 194, 682-683.

\section{SAMMANFATTNING \\ Försök att stimulera mitos hos odlade trofoblastceller från nötkreatursembryon.}

Ett lågt mitotiskt index hos odlade nörkreatursembryon begränsar bl a möjligheten till könsbestämning av embryon på cytogenetisk väg.

Syftet med försöket var att undersöka olika mitosstimulerande ämnens effekt på odlade trofoblastceller från 14 dagar gamla nötkreatursembryon. Trofoblast från vardera 1-5 embryon delades i 5 delar som odlades i Minimum Essential Medium med tillsats av $20 \%$ fetalt kalvserum (kontroll) och med tillsats av fyra olika mitogena substanser: Pokeweed, Phytohemagglutinin, Concanavalin A eller Thymidin. Ingen av substanserna visade sig ha någon mitosstimulerande effekt. Mitosindex var signifikant lägre vid tillsats av Pokeweed $(\mathrm{P}<0.05)$ och Thymidin $(\mathrm{P}<0.01)$ jämfört med kontrollen. Variationen $\mathrm{i}$ mitosindex mellan embryon var höggradigt signifikant $(\mathrm{P}<0.001)$.

(Received August 25, 1986).

Reprints may be requested from: Hans Gustafsson, Swedish Association for Livestock Breeding and Production, S-63184 Eskilstuna, Sweden. 